Review

\title{
Current Status of Immune Checkpoint Inhibitors in Gastrointestinal Cancers
}

\author{
Bum Jun Kim, Hyun Joo Jang, Hyeong Su Kim, Jung Han Kim ${ }^{凶}$ \\ Division of Hemato-Oncology, Department of Internal Medicine, Kangnam Sacred-Heart Hospital, Hallym University Medical Center, Hallym University \\ College of Medicine, Seoul 07441, Republic of Korea \\ $\square$ Corresponding author: Department of Internal Medicine, Kangnam Sacred-Heart Hospital, Hallym University Medical Center, Hallym University College of \\ Medicine, Seoul 07441, Republic of Korea Tel: +82-10-5392-5419, Fax: +82-2-3010-6961, E-mail: harricil@hallym.or.kr, harricil@hotmail.com \\ (C) Ivyspring International Publisher. This is an open access article distributed under the terms of the Creative Commons Attribution (CC BY-NC) license \\ (https://creativecommons.org/licenses/by-nc/4.0/). See http://ivyspring.com/terms for full terms and conditions.
}

Received: 2016.11.24; Accepted: 2017.02.24; Published: 2017.05.19

\begin{abstract}
The expansion of our understanding of tumor immunity and the recent success of new cancer immunotherapy has reignited the hope that we can treat cancer effectively with immunotherapeutic approaches. Immune checkpoint inhibitors have shown significant efficacy in the treatment of some solid and hematologic malignancies. Encouraged by recent success in some other types of malignancies, many clinical trials are ongoing to evaluate the efficacy of immune checkpoint inhibitors in gastrointestinal (GI) malignancies.

In this review, we briefly discuss theoretical background and current status of immune checkpoint inhibitors in Gl cancers. We summarize the key studies and present the ongoing clinical trials involving immune checkpoint inhibitors in Gl cancers.
\end{abstract}

Key words: cancer immunotherapy, gastrointestinal cancer, immune checkpoint inhibitor, review.

\section{Introduction}

The expansion of our understanding of tumor immunity and the recent success of new cancer immunotherapy has reignited the hope that we can treat cancer effectively with immunotherapeutic approaches [1]. Cancer cells can escape from immune surveillance and killing through adaptive immune suppression disabling tumor-specific $\mathrm{T}$ cells. There are two cytotoxic $\mathrm{T}$ cell immune checkpoint receptors that cause $\mathrm{T}$ cell downregulation and functional inhibition: programmed death-1 (PD-1) and cytotoxic T-lymphocyte associated antigen 4 (CTLA-4). Many types of tumors including gastrointestinal (GI) cancers express programmed death-ligand 1 (PD-L1) on their tumor cells, which are activated by PD-1 receptors on T cells. The interaction of PD-1 with PD-L1 promotes tumor immune escape by downregulating $T$ cell activation $[2,3]$. Immune checkpoint inhibitors have been designed to block PD-1 or CTLA-4 mediated inhibitory signals and restore antitumor immunity [3]. This type of immunotherapy has shown significant clinical benefits in the treatment of some solid and hematologic malignancies [4-13].

Since ipilimumab, a specific monoclonal antibody (mAb) to CTLA- 4 has been approved by the Food and Drug Administration (FDA) in 2011 for patients with malignant melanoma [4], immune checkpoint inhibitors have been explored in various types of cancers. Anti-programmed death-1 (anti-PD-1) and anti-programmed death ligand-1 (anti-PD-L1) mAbs were recently approved by the FDA in patients with malignant melanoma (nivolumab, pembrolizumab), non-small-cell lung cancer (NSCLC) (nivolumab, pembrolizumab, atezolimumab), renal cell carcinoma (nivolumab), head and neck squamous cell carcinoma (nivolumab, pembrolizumab), Hodgkin's lymphoma (nivolumab), and urothelial cancer (atezolimumab) [5-13].

Immunotherapy targeting cancer cells was assumed to be beneficial mainly in tumors with high immunogenicity. However, immune checkpoint inhibitors have been successful in cancers which 
hardly retain immunogenic nature $[6-8,10]$. Recently emerging data suggest that immune checkpoint inhibitors may also be effective in GI malignancies. Here we briefly review theoretical background and current status of immune checkpoint inhibitors in GI cancers. We also summarize the key studies and present the ongoing clinical trials involving immune check point inhibitors in GI cancers (Table 1 and Table 2).

\section{Colorectal cancer}

Llosa et al. demonstrated that the defect in mismatch repair (MMR) was associated with high CD8+ cytotoxic T-cells and Th1-type cells infiltration around the tumor [14]. Colorectal cancer (CRC) with microsatellite instability (MSI) has an exceptionally high mutation burden. Because increased presence of tumor-specific neoantigens in such hypermutated tumor is responsible for immune reaction, CRC patients with microsatellite instability high (MSI-H) may be good candidates for immune checkpoint inhibitors.
In 2015, Le el al. reported the results from a phase 2 study evaluating the efficacy of pembrolizumab in 41 refractory metastatic cancer patients with or without MMR-deficiency [15]. Among them, 11 patients had MMR-deficient CRC and 21 had MMR-proficient CRC. Pembrolizumab showed promising activity in patients with MMR-deficient CRC. The immune-related objective response rate was $40 \%$ in MMR-deficient CRC and $0 \%$ in MMR-proficient CRC, and the progression-free survival (PFS) rate at 12 weeks was $78 \%$ in MMR-deficient CC and 11\% in MMR-proficient CRC. In ESMO 2015, the preliminary results from the KEYNOTE-028 trial reported that overall response rate (ORR) and disease control rate of pembrolizumab in patients with PD-L1 positive advanced CRC were $4 \%$ and $22 \%$ [16]. Only one patient with MSI-H tumor achieved tumor response. With these sporadic reports suggesting that MSI status rather than PD-L1 expression may be a relevant biomarker for immune checkpoint inhibitors in $\mathrm{CRC}$, clinical trials have been designed using MSI status as a potential predictive biomarker.

Table 1. Key trials of immune checkpoint inhibitors in gastrointestinal cancers

\begin{tabular}{|c|c|c|c|c|c|c|}
\hline Cancer type & $\begin{array}{l}\text { Author, year/ } \\
\text { study name/status }\end{array}$ & Trial enrollment and description & ORR & $\begin{array}{l}\text { DOR } \\
\text { (months, } \\
\text { median) }\end{array}$ & $\begin{array}{l}\text { PFS } \\
\text { (months, } \\
\text { median) }\end{array}$ & $\begin{array}{l}\text { OS } \\
\text { (months, } \\
\text { median) }\end{array}$ \\
\hline \multirow[t]{3}{*}{$\begin{array}{l}\text { Colorectal } \\
\text { cancer }\end{array}$} & Le et al., 2015/published & $\begin{array}{l}\text { Phase 2, } 11 \text { patients with MMR-deficient CRC and } 21 \\
\text { patients with MMR proficient CRC; treated with } \\
\text { pembrolizumab }\end{array}$ & $\begin{array}{l}\text { dMMR: } 40 \% \\
\text { pMMR: } 0 \%\end{array}$ & NA & $\begin{array}{l}\text { dMMR: } \\
\text { NR } \\
\text { pMMR: } 2.2\end{array}$ & $\begin{array}{l}\text { dMMR: } \\
\text { NR } \\
\text { pMMR:5.0 }\end{array}$ \\
\hline & $\begin{array}{l}\text { O'Neil et al., 2015/ } \\
\text { KEYNOTE-028/preliminary }\end{array}$ & $\begin{array}{l}\text { Phase } 1 b, 23 \text { patients with PD-L1 positive advanced CRC; } \\
\text { treated with pembrolizumab }\end{array}$ & $\begin{array}{l}4 \% \\
\text { (1 responder: } \\
\text { MSI-H CRC) }\end{array}$ & NA & NA & NA \\
\hline & $\begin{array}{l}\text { Overman et al., 2016/ } \\
\text { CheckMate-142/preliminary }\end{array}$ & $\begin{array}{l}\text { Phase 2, } 100 \text { patients with MSI-H CRC and } 20 \text { patients with } \\
\text { MSS CRC; treated with nivolumab } 3 \mathrm{mg} / \mathrm{kg} \text { (N), or } \\
\text { nivolumab } 3 \mathrm{mg} / \mathrm{kg}+\text { ipilimumab } 1 \mathrm{mg} / \mathrm{kg}(\mathrm{N} 3 \mathrm{I} 1) \text {, or } \\
\text { nivolumab } 1 \mathrm{mg} / \mathrm{kg}+\text { ipilimumab } 3 \mathrm{mg} / \mathrm{kg} \text { (N1I3) }\end{array}$ & $\begin{array}{l}\text { MSI-H } \\
-\mathrm{N}: 26 \% \\
\text {-N3I1: 33\% } \\
\text { MSS } \\
\text {-N1I3: } 10 \% \\
\text {-N3I1: } 0 \%\end{array}$ & $\begin{array}{l}\text { MSI-H } \\
\text {-N: NR } \\
\text {-N3I1: NR } \\
\text { MSS } \\
\text {-N1I3: NA } \\
\text {-N3I1: NA }\end{array}$ & $\begin{array}{l}\text { MSI-H } \\
-\mathrm{N}: 5.3 \\
\text {-N3I1: NR } \\
\text { MSS } \\
\text {-N1I3: } 2.3 \\
\text {-N3I1: } 1.3\end{array}$ & $\begin{array}{l}\text { MSI-H } \\
\text {-N: 17.1 } \\
\text {-N3I1: NR } \\
\text { MSS } \\
\text {-N1I3: } 11.5 \\
\text {-N3I1: } 3.7\end{array}$ \\
\hline $\begin{array}{l}\text { Hepatocellular } \\
\text { carcinoma }\end{array}$ & $\begin{array}{l}\text { Melero et al., 2016/ } \\
\text { CheckMate-040/preliminary }\end{array}$ & $\begin{array}{l}\text { Phase } 1 / 2,48 \text { HCC patients in dose escalation cohort (ES) } \\
\text { and } 214 \text { HCC patients in dose expansion cohort (EX); treated } \\
\text { with nivolumab }\end{array}$ & $\begin{array}{l}\text { ES: } 15 \% \\
\text { EX: } 16 \%\end{array}$ & $\begin{array}{l}\text { ES: } 17 \\
\text { EX: NR }\end{array}$ & $\begin{array}{l}\text { ES: NA } \\
\text { EX: NA }\end{array}$ & $\begin{array}{l}\text { ES: } 14.3 \\
\text { EX: NA }\end{array}$ \\
\hline \multirow[t]{3}{*}{ Gastric cancer } & $\begin{array}{l}\text { Muro et al., 2016/ } \\
\text { KEYNOTE-012/published }\end{array}$ & $\begin{array}{l}\text { Phase } 1 b, 39 \text { patients with recurrent or metastatic PD-L1 } \\
\text { positive gastric cancer; treated with pembrolizumab }\end{array}$ & $22 \%$ & 9.3 & 1.9 & 11.4 \\
\hline & $\begin{array}{l}\text { Janjigian et al.,2016/ } \\
\text { CheckMate-032/preliminary }\end{array}$ & $\begin{array}{l}\text { Phase } 1 / 2,160 \text { patients with stage IV gastric or } \\
\text { gastroesophageal junction adenocarcinoma; treated with } \\
\text { nivolumab } 3 \mathrm{mg} / \mathrm{kg}(\mathrm{N}) \text {, or nivolumab } 3 \mathrm{mg} / \mathrm{kg}+ \\
\text { ipilimumab } 1 \mathrm{mg} / \mathrm{kg} \text { (N3I1), or nivolumab } 1 \mathrm{mg} / \mathrm{kg}+ \\
\text { ipilimumab } 3 \mathrm{mg} / \mathrm{kg} \text { (N1I3) }\end{array}$ & $\begin{array}{l}\text { N: } 14 \% \\
\text { N3I1: } 10 \% \\
\text { N1I3: } 26 \%\end{array}$ & $\begin{array}{l}\text { N: NA } \\
\text { N3I1: NA } \\
\text { N1I3: NA }\end{array}$ & $\begin{array}{l}\text { N: } 1.36 \\
\text { N3I1: } 1.58 \\
\text { N1I3: } 1.45\end{array}$ & $\begin{array}{l}\text { N: } 5.03 \\
\text { N3I1: } 4.83 \\
\text { N1I3: } 6.87\end{array}$ \\
\hline & $\begin{array}{l}\text { Fuchs et al., 2016/ } \\
\text { KEYNOTE-059/preliminary }\end{array}$ & $\begin{array}{l}\text { Phase 2, } 18 \text { patients with HER2 negative recurrent or } \\
\text { metastatic gastric or gastroesophageal junction } \\
\text { adenocarcinoma; treated with pembrolizumab }+5-\mathrm{FU}+ \\
\text { cisplatin }\end{array}$ & NA & NA & NA & NA \\
\hline $\begin{array}{l}\text { Esophageal } \\
\text { cancer }\end{array}$ & $\begin{array}{l}\text { Doi et al., 2016/ } \\
\text { KEYNOTE-028/preliminary }\end{array}$ & $\begin{array}{l}\text { Phase } 1 \mathrm{~b}, 23 \text { patients with PD-L1 positive advanced } \\
\text { esophageal cancer; treated with pembrolizumab }\end{array}$ & $30 \%$ & NR & NA & NA \\
\hline Biliary cancer & $\begin{array}{l}\text { Bang et al., 2015/ } \\
\text { KEYNOTE-028/preliminary }\end{array}$ & $\begin{array}{l}\text { Phase } 1 \mathrm{~b}, 24 \text { patients with PD-L1 positive advanced biliary } \\
\text { tract cancer; treated with pembrolizumab }\end{array}$ & $17 \%$ & NA & NA & NA \\
\hline
\end{tabular}

CRC, colorectal cancer; dMMR, mismatch repair deficient; DOR, duration of response; 5-FU, 5-fluorouracil; MSI-H, microsatellite instability-high; MSS, microsatellite stable; NA, not applicable; NR, not reached; ORR, overall response rate; OS, overall survival; PD-L1, programmed death ligand-1; PFS, progression-free survival; pMMR, mismatch repair proficient. 
Table 2. Ongoing clinical trials of immune checkpoint inhibitors in gastrointestinal cancers

\begin{tabular}{|c|c|c|c|c|c|}
\hline Cancer type & Trial identifier & Title & Phase & Target $n$ & Sponsor \\
\hline \multirow[t]{2}{*}{$\begin{array}{l}\text { Colorectal } \\
\text { cancer }\end{array}$} & NCT02460198 & $\begin{array}{l}\text { A phase } 2 \text { study of pembrolizumab (MK-3475) as monotherapy in subjects } \\
\text { with previously treated locally advanced unresectable or metastatic (stage } \\
\text { IV) dMMR or MSI-H CRC (KEYNOTE-164) }\end{array}$ & 2 & 120 & Merck Sharp \& Dohme Corp. \\
\hline & NCT02563002 & $\begin{array}{l}\text { A phase } 3 \text { study of pembrolizumab (MK-3475) vs. chemotherapy indMMR } \\
\text { or MSI-H stage IV CRC (KEYNOTE-177) }\end{array}$ & 3 & 270 & Merck Sharp \& Dohme Corp. \\
\hline \multirow[t]{4}{*}{$\begin{array}{l}\text { Hepatocellular } \\
\text { carcinoma }\end{array}$} & NCT02576509 & $\begin{array}{l}\text { A randomized, multi-center phase } 3 \text { study of nivolumab versus sorafenib } \\
\text { as first-line treatment in patients with advanced HCC (CheckMate-459) }\end{array}$ & 3 & 726 & Bristol-Myers Squibb \\
\hline & NCT02702401 & $\begin{array}{l}\text { A phase } 3 \text { study of pembrolizumab (MK-3475) vs. best supportive care as } \\
\text { second-line therapy in subjects with previously systemically treated } \\
\text { advanced HCC (KEYNOTE-240) }\end{array}$ & 3 & 408 & Merck Sharp \& Dohme Corp. \\
\hline & NCT02702414 & $\begin{array}{l}\text { A phase } 2 \text { study of pembrolizumab (MK-3475) as monotherapy in subjects } \\
\text { with previously systemically treated advanced HCC (KEYNOTE-224) }\end{array}$ & 2 & 100 & Merck Sharp \& Dohme Corp. \\
\hline & NCT02423343 & $\begin{array}{l}\text { A phase } 1 \mathrm{~b} / 2 \text { dose escalation and cohort expansion study of the safety, } \\
\text { tolerability and efficacy of a novel transforming growth factor-beta } \\
\text { receptor } 1 \text { kinase inhibitor (galunisertib) administered in combination } \\
\text { with anti-PD-1 (nivolumab) in advanced refractory solid tumors (phase } \\
\text { 1b) and in recurrent or refractory non-small cell lung cancer, } \\
\text { hepatocellular carcinoma, or glioblastoma (phase 2) }\end{array}$ & $1 b / 2$ & 100 & Eli Lilly and Company \\
\hline \multirow[t]{5}{*}{$\begin{array}{l}\text { Stomach } \\
\text { cancer }\end{array}$} & NCT02370498 & $\begin{array}{l}\text { A Phase 3, randomized, open-label clinical trial of pembrolizumab } \\
\text { (MK-3475) versus paclitaxel in subjects with advanced gastric or } \\
\text { gastroesophageal junction adenocarcinoma who progressed after first-line } \\
\text { therapy with platinum and fluoropyrimidine (KEYNOTE-061) }\end{array}$ & 3 & 720 & Merck Sharp \& Dohme Corp. \\
\hline & NCT02494583 & $\begin{array}{l}\text { A randomized, active-controlled, partially blinded, biomarker select, } \\
\text { phase } 3 \text { clinical trial of pembrolizumab as monotherapy and in } \\
\text { combination with cisplatin+5-FU versus placebo+cisplatin+5-FU as } \\
\text { first-line treatment in subjects with advanced gastric or gastroesophageal } \\
\text { junction adenocarcinoma (KEYNOTE-062) }\end{array}$ & 3 & 750 & Merck Sharp \& Dohme Corp. \\
\hline & NCT02872116 & $\begin{array}{l}\text { A randomized, multicenter, open-label, phase } 3 \text { study of nivolumab plus } \\
\text { ipilimumab versus oxaliplatin plus fluoropyrimidine in subjects with } \\
\text { previously untreated advanced or metastatic gastric or gastroesophageal } \\
\text { junction cancer (CheckMate-649) }\end{array}$ & 3 & 870 & Bristol-Myers Squibb \\
\hline & NCT02267343 & $\begin{array}{l}\text { ONO- } 4538 \text { (nivolumab) phase } 3 \text { study a Multicenter, double-blind, } \\
\text { randomized study in patients with unresectable advanced or recurrent } \\
\text { gastric cancer }\end{array}$ & 3 & 480 & Ono Pharmaceutical Co. Ltd \\
\hline & NCT02746796 & $\begin{array}{l}\text { ONO- } 4538 \text { (nivolumab) phase } 2 \text { study a multicenter, open-label } \\
\text { randomized study in patients with unresectable advanced or recurrent } \\
\text { gastric cancer }\end{array}$ & 2 & 268 & Ono Pharmaceutical Co. Ltd \\
\hline \multirow[t]{4}{*}{$\begin{array}{l}\text { Esophageal } \\
\text { cancer }\end{array}$} & NCT02559687 & $\begin{array}{l}\text { A phase } 2 \text { study of pembrolizumab monotherapy in third-line previously } \\
\text { treated subjects with advanced/metastatic adenocarcinoma or squamous } \\
\text { cell carcinoma of the esophagus or advanced/metastatic Siewert type I } \\
\text { adenocarcinoma of the esophagogastric junction (KEYNOTE-180) }\end{array}$ & 2 & 100 & Merck Sharp \& Dohme Corp. \\
\hline & NCT02564263 & $\begin{array}{l}\text { A phase 3randomized open-label study of single agent pembrolizumab vs } \\
\text { physicians' choice of single agent docetaxel, paclitaxel, or irinotecan in } \\
\text { subjects with advanced/metastatic adenocarcinoma and squamous cell } \\
\text { carcinoma of the esophagus that have progressed after first-sine standard } \\
\text { therapy (KEYNOTE-181) }\end{array}$ & 3 & 600 & Merck Sharp \& Dohme Corp. \\
\hline & NCT02569242 & $\begin{array}{l}\text { ONO-4538 (nivolumab) phase } 3 \text { study amulticenter, randomized, } \\
\text { open-label study in patients with unresectableadvanced or recurrent } \\
\text { esophageal cancer }\end{array}$ & 3 & 390 & Ono Pharmaceutical Co. Ltd \\
\hline & NCT02743494 & $\begin{array}{l}\text { Randomized, multicenter, double blind, phase } 3 \text { study of adjuvant } \\
\text { nivolumab or placebo in subjects with resected esophageal, or } \\
\text { gastroesophageal junction cancer }\end{array}$ & 3 & 760 & Bristol-Myers Squibb \\
\hline
\end{tabular}

In ESMO 2016, Overman et al. reported the preliminary results from the CheckMate-142, a two-staged phase 2 study evaluating nivolumab +/ipilimumab in metastatic or recurrent CRC with MSI-H or microsatellite stable (MSS) [17]. The ORR in MSI-H CRC was $26 \%$ with nivolumab monotherapy and $33 \%$ with nivolumab plus ipilimumab, and the toxicity profile of combination therapy was tolerable with $27 \%$ of grade $3 / 4$ adverse events (AEs). Efficacy analysis of nivolumab plus ipilimumab in patients with MSS CRC showed poor ORR with less than $10 \%$. With these promising results in MSI-H CRC, several clinical trials evaluating pembrolizumab as a first-line or salvage treatment in patients with MSI-H or MMR deficient CRC are ongoing [Identifier: NCT02563002, NCT02460198].

Additionally, immune checkpoint inhibitors as a combination partner for cytotoxic chemotherapy in CRC are under investigation. In ESMO 2016, Stenehjem et al. reported the preliminary results of phase 1 dose escalation trial assessing safety and efficacy of pembrolizumab combined with modified FOLFOX6 in advanced gastrointestinal malignancies including 7 CRC patients [18]. The combination of modified FOLFOX6 with pembrolizumab has an acceptable safety profile with ORR of $29 \%$. 


\section{Hepatocellular carcinoma}

Hepatocellular carcinoma (HCC) is typically an inflammation-associated cancer and, thus, is often immunogenic [19]. During the development of HCC, intricate immunosuppressive mechanisms in the tumor microenvironment may become activated and further interfere with the induction of meaningful anti-tumor immune response. Multiple immunosuppressive mechanisms have been proposed, including up-regulation of immune checkpoint pathway [20-22]. In preclinical model, blockage of the PD-1 receptor combined with administration of immunostimulatory mAbs extends survival in murine model of HCC $[23,24]$. On the basis of these results, it is expected that immune checkpoint inhibitors may boost host immunity and improve clinical outcomes in patients with HCC.

In ESMO 2016, Melero et al. reported the preliminary results from the phase $1 / 2$ CheckMate-040 study evaluating the safety and efficacy of nivolumab in patients with advanced HCC [25]. After dose-escalation stage involving 48 patients, dose-expansion stage with nivolumab ( $3 \mathrm{mg} / \mathrm{kg}$ ) involving 214 patients was processed. Various types of cohort such as sorafenib-naive/intolerant patients or sorafenib-failures, patients infected with hepatitis $\mathrm{C}$ virus (HCV) or hepatitis B virus (HBV), or patients with no hepatitis virus infection were included in the dose-expansion stage. Nivolumab showed similar toxicity profile with what has been observed in other tumor types with maximum $16 \%$ of grade $3 / 4$ aspartate transaminase elevation in $\mathrm{HCV}$-infected cohort. The ORRs were 15\% (7/48) in the escalating cohort and 16\% (35/214) in the expansion cohort. Out of a total of 262 patients, 5 achieved complete response (CR). Median duration of response was 17 months in the dose-escalation stage and was not reached in the dose-expansion stage. Nivolumab also showed promising outcome in terms of overall survival (OS), with survival rate of $71 \%$ at 9 months in the dose-expansion stage.

Several clinical trials with immune checkpoint inhibitors are ongoing in patients with HCC. Comparison of nivolumab with sorafenib as a first-line treatment for patients with HCC is under investigation in the phase 3 CheckMate- 459 trial [Identifier: NCT02576509]. Pembrolizumab monotherapy is being evaluated in phase 2 and phase 3 trials of HCC patients who progressed or intolerant to sorafenib [Identifier: NCT02702401, NCT02702414]. Additionally, safety and efficacy of nivolumab in combination with transforming growth factor-beta receptor 1 kinase inhibitor (galunisertib) are being investigated in phase $1 \mathrm{~b} / 2$ clinical trial involving 25 HCC patients [Identifier: NCT02423343].

\section{Gastric cancer}

Recently, the cancer genome atlas has identified that gastric cancer can be classified by molecular subtype; Epstein Barr virus (EBV) positive, microsatellite unstable, genomically stable, and chromosomal instability tumors [26]. Among these molecular subtypes, EBV-associated tumors are associated with elevated PD-L1/2 expression, which makes this subtype or tumors attractive for immunotherapy targeting PD-1 and its ligands. Additionally, microsatellite unstable tumors have hypermutated phenotype, which has been associated with better response to immune checkpoint inhibitor in other malignancies [15]. With these plausible implications for the use of immune check point inhibitors in gastric cancer, various clinical trials have been undertaken.

In May 2016, the results of the phase $1 \mathrm{~b}$ KEYNOTE-012 trial, the first clinical study evaluating the safety and the efficacy of immune checkpoint inhibitor (pembrolizumab) in patients with gastric cancer, were published [27]. Thirty-nine patients with PD-L1 positive recurrent or metastatic gastric cancer were enrolled, and the ORR was $22 \%$ without CR and incidence of grade 3 or 4 AEs were $13 \%$. Pembrolizumab was also evaluated as a combination partner to 5-fluorouracil plus cisplatin (FP) for first-line treatment of advanced gastric cancer. Preliminary safety data of the phase II KEYNOTE-059 trial were reported in GI ASCO 2016 [28]. In this trial, pembrolizumab in combination with FP was introduced as a first-line therapy in 18 patients with advanced gastric cancer (AGC) and showed manageable safety profile with no treatment-related discontinuations or deaths. AEs of interest based on immune etiology were grade 2 infusion-related reaction and grade 2 pruritus ( $n=1$ [5.9\%] each). Further studies for the safety and efficacy of pembrolizumab as monotherapy or combination therapy in AGC patients are ongoing. The KEYNOTE-061 trial is a randomized phase 3 study which is designed to evaluate pembrolizumab versus paclitaxel after failure of first-line platinum plus fluoropyrimidine for patients with AGC [NCT02370498]. The ongoing KEYNOTE-062 study is a randomized phase 3 trial to evaluate pembrolizumab in combination with FP as first-line treatment in AGC patients [Identifier: NCT02494583].

Nivolumab was also evaluated in patients with AGC. In ASCO 2016, the preliminary results of the phase 1/2 CheckMate-032 trial were reported [29]. In this trial, nivolumab alone or in combination with ipilimumab was evaluated as a salvage treatment in 160 AGC patients. The ORR was numerically higher in the nivolumab $(1 \mathrm{mg} / \mathrm{kg})$ plus ipilimumab (3 
$\mathrm{mg} / \mathrm{kg}$ ) combination arm $(26 \%)$ than the nivolumab monotherapy arm (14\%) or the nivolumab (3 mg/ kg) plus ipilimumab $(1 \mathrm{mg} / \mathrm{kg})$ combination arm $(10 \%)$. The ORR was reached up to $44 \%$ in the $\geq 1 \%$ PD-L1 expression subgroup of nivolumab $(1 \mathrm{mg} / \mathrm{kg})$ plus ipilimumab ( $3 \mathrm{mg} / \mathrm{kg}$ ) combination arm. Grade 3 or 4 AEs occurred in $45 \%$ of patients treated with nivolumab ( $1 \mathrm{mg} / \mathrm{kg}$ ) plus ipilimumab $(3 \mathrm{mg} / \mathrm{kg})$ and were generally manageable. Further phase 3 trial evaluating the efficacy of nivolumab plus ipilimumab as first-line treatment in patients with AGC is recruiting participants [Identifier: NCT02872116]. Other phase 3 trial comparing the efficacy of nivolumab to placebo in chemotherapy-refractory AGC is ongoing [Identifier: NCT02267343]. Nivolumab in combination with TS-1 (tegafur/gimeracil/oteracil potassium) plus oxaliplatin or capecitabine plus oxaliplatin will be evaluated as first-line treatment in two-staged phase II study [Identifier: NCT02746796].

The preliminary results of phase 2 trial evaluating the efficacy of ipilimumab alone versus best supportive care as sequential/maintenance therapy in patients with unresectable, locally advanced/metastatic gastric or gastro-esophageal junction cancer following first-line chemotherapy with platinum plus fluoropyrimidine were reported [30]. In this trial with 114 patients enrolled, ipilimumab showed no favorable outcomes in terms of immune-related PFS which was the primary endpoint.

\section{Esophageal cancer}

There is few available clinical data regarding immune checkpoint blockades in esophageal cancer. The preliminary results of phase $1 \mathrm{~b}$ multi-cohort KEYNOTE-028 trial are the only available data. Doi et al. presented at ASCO GI 2016 the update results for the advanced esophageal carcinoma cohort of the phase $1 \mathrm{~b}$ KEYNOTE-028 study evaluating pembrolizumab in patients with PD-L1 positive advanced solid tumors [31]. Pembrolizumab showed promising results with the ORR of $30.4 \%$ and PFS rate of $21.7 \%$ at 12 months in patients with PD-L1 positive, heavily treated esophageal cancer. Phase 2 study [Identifier: NCT02559687] of pembrolizumab monotherapy for third-line treatment and phase 3 study [Identifier: NCT02564263] of pembrolizumab monotherapy for second-line treatment in esophageal cancer are ongoing. Clinical trials of nivolumab as a rescue treatment [Identifier: NCT02569242] and adjuvant treatment [Identifier: NCT02743494] are also in progress for esophageal cancer patients.

\section{Biliary tract cancer}

Ye et al. reported that PD-L1 and PD-1 expression is upregulated in intrahepatic cholangiocarcinoma [32]. However, plausible mechanism for immune checkpoint inhibitors in biliary tract cancer is not well established and available clinical data is very limited. In ESMO 2015, Bang et al. reported the preliminary results of patients with advanced biliary tract cancer from the ongoing phase $1 b$, multi-cohort KEYNOTE-028 study [33]. Twenty-four patients with PD-L1 positive adenocarcinoma of the biliary tract or gallbladder received pembrolizumab monotherapy and the ORR was $17.4 \%$.

\section{Future perspective}

Current approaches in cancer immunotherapy are shifting to multimodality or combination strategies. First of all, conventional cytotoxic chemotherapy can be combined with immune checkpoint inhibitors. Chemotherapeutic agents destroy tumor cells and usually release intracellular peptides, RNA, and proteins which may become useful tumor associated antigens to enhance the efficacy of immune checkpoint inhibitors. Based on immune modulating properties of vascular endothelial growth factor (VEGF) to hamper infiltration of $\mathrm{T}$ cells and dendritic cells into tumors, immune checkpoint inhibitors can be combined with VEGF inhibitors, such as bevacizumab and ziv-aflibercept. As suggested in advanced melanoma and NSCLC, PD-1/PD-L1 blockade may be an attractive combination partner with anti-CTLA-4 mAbs (ipilimumab or tremelimumab) in GI cancers. Trials combining immune checkpoint inhibitors with immune stimulatory antibodies, such as $\mathrm{CD} 137$-specific $\mathrm{mAb}$, are under investigation. In addition, cancer vaccines may be also combined with immune checkpoint inhibitors.

\section{Conclusion}

Immune checkpoint inhibitors are leading recent renaissance of cancer immunotherapy. Encouraged by recent success in some other types of malignancies, many clinical trials have also been undertaken to evaluate the efficacy of immune checkpoint inhibitors in GI malignancies. Early studies have suggested that immune checkpoint inhibition might be effective in some patients with GI cancers. Up to date, however, the era of immunotherapy in GI cancers is in an inchoate stage. The immune suppressive mechanisms and microenvironment surrounding GI cancers are still obscure compared with malignant melanoma, renal cell carcinoma, or NSCLC. To improve the 
efficacy of immune checkpoint inhibitors in GI cancers, we should build more profound understanding of tumor immune system and microenvironment. In addition, we need to identify adequate biomarkers that can predict the efficacy of this type of immunotherapy. Translational researches have proposed several tumor-derived biomarkers (PD-L1 expression, tumor mutational load, and neoantigens) and immune cell-derived biomarkers (tumor infiltrating lymphocytes in tumor microenvironments, PD-L1 expression on immune cells, and the ratio of effector $\mathrm{CD} 8+\mathrm{T}$ cells to regulatory $\mathrm{T}$ cells with FoxP3). However, future studies are needed to reveal the role of PD-L1 expression and these possible biomarkers in predicting response to immune checkpoint inhibitors in GI cancers. We hope that ongoing clinical trials provide meaningful information for these issues.

\section{Competing Interests}

The authors have declared that no competing interest exists.

\section{References}

1. Kim JH, Kim BJ, Kim HS, Kim JH. Current status and perspective of immunotherapy in gastrointestinal cancers. J Cancer. 2016;7:1599-604.

2. Korman AJ, Peggs KS, Allison JP. Checkpoint blockade in cancer immunotherapy. Adv Immunol. 2006;90:297-339.

3. Pardoll DM. The blockade of immune checkpoints in cancer immunotherapy. Nat Rev Cancer. 2012;12:252-64.

4. Robert C, Thomas L, Bondarenko I, O'Day S, Weber J, Garbe C, et al. Ipilimumab plus dacarbazine for previously untreated metastatic melanoma. N Engl J Med. 2011;364:2517-26.

5. Robert C, Schachter J, Long GV, Arance A, Grob JJ, Mortier L, et al Pembrolizumab versus ipilimumab in advanced melanoma. N Engl J Med. 2015;372:2521-32.

6. Seiwert TY, Burtness B, Mehra R, Weiss J, Berger R, Eder JP, et al. Safety and clinical activity of pembrolizumab for treatment of recurrent or metastatic squamous cell carcinoma of the head and neck (KEYNOTE-012): an open-label, multicentre, phase 1b trial. Lancet Oncol. 2016;17:956-65.

7. Brahmer J, Reckamp KL, Baas P, Crinò L, Eberhardt WE, Poddubskaya E, et al. Nivolumab versus docetaxel in advanced squamous-cell non-small-cell lung cancer. N Engl J Med. 2015;373:123-35.

8. Reck M, Rodríguez-Abreu D, Robinson AG, Hui R, Csőszi T, Fülöp A, et al. Pembrolizumab versus chemotherapy for PD-L1-positive non-small-cell lung cancer. N Engl J Med. 2016; 375:1823-33.

9. Motzer RJ, Escudier B, McDermott DF, George S, Hammers HJ, Srinivas S, et al. Nivolumab versus everolimus in advanced renal-cell carcinoma. N Engl J Med. 2015;373:1803-13.

10. Ferris RL, Blumenschein G Jr, Fayette J, Guigay J, Colevas AD, Licitra L, et al. Nivolumab for recurrent squamous-cell carcinoma of the head and neck. $\mathrm{N}$ Engl J Med. 2016;375:1856-67.

11. Younes A, Santoro A, Shipp M, Zinzani PL, Timmerman JM, Ansell S, et al. Nivolumab for classical Hodgkin's lymphoma after failure of both autologous stem-cell transplantation and brentuximab vedotin: a multicentre, multicohort, single-arm phase 2 trial. Lancet Oncol. 2016;17:1283-94.

12. Fehrenbacher L, Spira A, Ballinger M, Kowanetz M, Vansteenkiste J, Mazieres $\mathrm{J}$, et al. Atezolizumab versus docetaxel for patients with previously treated non-small-cell lung cancer (POPLAR): a multicentre, open-label, phase 2 randomised controlled trial. Lancet. 2016; 387:1837-46.

13. Rosenberg JE, Hoffman-Censits J, Powles T, van der Heijden MS, Balar AV Necchi A, et al. Atezolizumab in patients with locally advanced and metastatic urothelial carcinoma who have progressed following treatment with platinum-based chemotherapy: a single-arm, multicentre, phase 2 trial. Lancet. 2016:387:1909-20.

14. Llosa NJ, Cruise M, Tam A, Wicks EC, Hechenbleikner EM, Taube JM, et al. The vigorous immune microenvironment of microsatellite instable colon cancer is balanced by multiple counter-inhibitory checkpoints. Cancer Discov. 2015;5:43-51.

15. Le DT, Uram JN, Wang H, Bartlett BR, Kemberling H, Eyring AD, et al. PD-1 blockade in tumors with mismatch repair deficiency. $\mathrm{N}$ Engl J Med. 2015;372:2509-20.
16. O'Neil BH, Wallmark J, Lorente D, Elez E, Raimbourg J, Gomez-Roca C, et al. Pembrolizumab (MK-3475) for patients with advanced colorectal carcinoma (CRC): Preliminary results from KEYNOTE-028. Eur J Cancer. 2015;51 (suppl 3):abstr502

17. Overman MJ, Kopetz S, Lonardi S, McDermott R, Leone F, Leach J, et al. Nivolumab \pm ipilimumab treatment efficacy, safety, and biomarkers in patients with metastatic colorectal cancer with and without high microsatellite instability (MSI-H): results from the CheckMate-142 study. Ann Oncol. 2016;27 (suppl 6):abstr479P.

18. Stenehjem D, Gupta S, Wade M, Gilcrease G, Garrido-Laguna I, Weis JR, et al. A phase I dose escalation trial to assess the safety and preliminary efficacy of mFOLFOX6 combined with pembrolizumab (MK3475) in advanced gastrointestinal malignancies. Ann Oncol. 2016;27 (suppl 6):071P.

19. Hato T, Goyal L, Greten TF, Duda DG, Zhu AX. Immune checkpoint blockade in hepatocellular carcinoma: current progress and future directions. Hepatology. 2014;60:1776-82.

20. Wang BJ, Bao JJ, Wang JZ, Wang Y, Jiang M, Xing MY, et al. Immunostaining of PD-1/PD-Ls in liver tissues of patients with hepatitis and hepatocellular carcinoma. World J Gastroenterol. 2011;17:3322-9.

21. Gao Q, Wang XY, Qiu SJ, Yamato I, Sho M, Nakajima Y, et al. Overexpression of PD-L1 significantly associates with tumor aggressiveness and postoperative recurrence in human hepatocellular carcinoma. Clin Cancer Res. 2009;15:971-9.

22. Zeng Z, Shi F, Zhou L, Zhang MN, Chen $Y$, Chang XJ, et al. Upregulation of circulating PD-L1/PD-1 is associated with poor post-cryoablation prognosis in patients with HBV-related hepatocellular carcinoma. PloS One. 2011;6:e23621.

23. Chen Y, Ramjiawan RR, Reiberger T, Ng MR, Hato T, Huang Y, et al. CXCR4 inhibition in tumor microenvironment facilitates anti-programmed death receptor-1 immunotherapy in sorafenib-treated hepatocellular carcinoma in mice. Hepatology. 2015;61:1591-602.

24. Morales-Kastresana A, Sanmamed MF, Rodriguez I, Palazon A, Martinez-Forero I, Labiano S, et al. Combined immunostimulatory monoclonal antibodies extend survival in an aggressive transgenic hepatocellular carcinoma mouse model. Clin Cancer Res. 2013;19:6151-62.

25. Melero I, Sangro B, Yau T, Hsu C, Kudo M, Crocenzi TS, et al. Safety and preliminary efficacy of nivolumab in patients with advanced hepatocellular carcinoma: interim analysis of the phase 1/2 CheckMate 040 study. Ann Oncol. 2016;27 (suppl 6):abstr615O

26. Cancer Genome Atlas Research Network. Comprehensive molecular characterization of gastric adenocarcinoma. Nature. 2014;13:202-9.

27. Muro K, Chung HC, Shankaran V, Geva R, Catenacci D, Gupta S, et al. Pembrolizumab for patients with PD-L1-positive advanced gastric cancer (KEYNOTE-012): a multicentre, open-label, phase $1 \mathrm{~b}$ trial. Lancet Oncol. 2016;17:717-26.

28. Fuchs CS, Ohtsu A, Tabernero J, Cutsem EV, Wang JD, Lam B, et al. Preliminary safety data from KEYNOTE-059: pembrolizumab plus 5-fluorouracil (5-FU) and cisplatin for first-line treatment of advanced gastric cancer. J Clin Oncol. 2016;34 (suppl 4S):abstr161.

29. Janjigian YY, Bendell JC, Calvo E, Kim JW, Ascierto PA, Sharma P, et al. CheckMate-032: Phase I/II, open-label study of safety and activity of nivolumab alone or with ipilimumab in advanced and metastatic gastric cancer. J Clin Oncol. 2016;34 (suppl):abstr4010.

30. Moehler MH, Cho JY, Kim YH, Kim JW, Bartolomeo MD, Ajani JA, et al. A randomized, open-label, two-arm phase II trial comparing the efficacy of sequential ipilimumab versus best supportive care following first-line chemotherapy in patients with unresectable, locally advanced/metastatic gastric or gastro-esophageal junction cancer. J Clin Oncol. 2016;34 (suppl):abstr4011.

31. Doi T, Piha-Paul SA, Jalal SI, Mai-Dang H, Saraf S, Koshiji M, et al. Updated results for the advanced esophageal carcinoma cohort of the phase $1 \mathrm{~b}$ KEYNOTE-028 study of pembrolizumab. J Clin Oncol. 2016;34 (suppl 4S):abstr7.

32. Ye Y, Zhou L, Xie X, Jiang G, Xie H, Zheng S. Interaction of B7-H1 on intrahepatic cholangiocarcinoma cells with PD-1 on tumor-infiltrating T cells as a mechanism of immune evasion. J Surg Oncol. 2009;100:500-4.

33. Bang YJ, et al. Safety and efficacy of pembrolizumab (MK-3475) in patients with advanced biliary tract cancer: Interim results of KEYNOTE-028. Eur J Cancer. 2016;51 (suppl 3):abstr525. 